\title{
Natural Conservation Base on Management of Sacred Cultural Landscape of Catur Angga Batukaru Temple in Tabanan-Bali
}

\author{
I Nyoman Wardi ${ }^{\text {** }}$ \\ ${ }^{a}$ Departement of Archaeology Faculty of Arts, Udayana University, Denpasar, Bali-Indonesia \\ *Email: wardiecoculture@gmail.com
}

Diterima (received) 13 Desember 2019; disetujui (accepted) 1 Februari 2020; tersedia secara online (available online) 1 Februari 2020

\begin{abstract}
The study aimed to discuss the characteristic and environmental wisdom of the sacred Cultural Landscape of Catur Angga Batukaru temples in the conservation of natural resources in the regency of Tabanan-Bali. To reveal the research problems, data collection was conducted through observation, in-depth interview, and document study. The collected data were analyzed by the descriptivequalitative technique. The results showed the structure of cultural landscape of Catur Angga Batukaru Temple consists of five cultural heritages as single vortices (sacred cultural landscape). The Batukaru Temple as a center with two main segments as subordinates, on west side, consists of Muncaksari and Tambawaras Temple, and on east side, consists of Petali and Besi Kalung Temple. Each unit managed by local communities generally comes from the Bali Age people. The management consists of the pengempon's group temple, the institution of traditional villages, and subak's in the surrounding. As a living monument (temple), functioned as a sacred place to invoke safety, agricultural fertility, health, peace, and political stability. Similarly, through myth, ritual, and emission values the sanctity of the magical-religious, its cultural landscape located in the upstream region indirectly contribute very important to the conservation of the natural environment. As well as, the ritual uniqueness and aesthetic architectural values and beauty of the natural environment are so potential to be developed as a tourist attraction. In the modern era, in environmental degradation, it's very important to improve the welfare of local communities and conserving the natural environment in the context of sustainable development in Tabanan-Bali.
\end{abstract}

Keywords: sacred cultural landscape; catur angga batukaru; management; conservation

\begin{abstract}
Abstrak
Penelitian ini bertujuan untuk membahas karakteristik dan kearifan lingkungan dari Lanskap Budaya sakral Pura Catur Angga Batukaru dalam konservasi sumber daya alam di Kabupaten Tabanan-Bali. Untuk mengungkap masalah penelitian, pengumpulan data dilakukan melalui observasi, wawancara mendalam, dan studi dokumen. Data yang terkumpul dianalisis dengan teknik deskriptif kualitatif. Hasil penelitian menunjukkan struktur lanskap budaya Pura Catur Angga Batukaru terdiri dari lima warisan budaya sebagai pusaran tunggal (lanskap budaya sakral). Pura Batukaru sebagai pusat dengan dua ruas utama sebagai bawahannya, di sisi barat terdiri dari Pura Muncaksari dan Tambawaras, dan di sisi timur terdiri dari Pura Petali dan Besi Kalung. Setiap unit yang dikelola oleh masyarakat lokal umumnya berasal dari masyarakat Bali Age. Pengelolanya terdiri dari kelompok pengempon pura, kelembagaan desa adat, dan subak di sekitarnya. Sebagai monumen hidup (pura), difungsikan sebagai tempat suci untuk memohon keselamatan, kesuburan pertanian, kesehatan, perdamaian, dan stabilitas politik. Demikian pula melalui mitos, ritual, dan nilai emisi kesucian magis-religius, lanskap budayanya yang berada di kawasan hulu secara tidak langsung memberikan kontribusi yang sangat penting bagi kelestarian lingkungan alam. Selain itu, keunikan ritual dan nilai estetika arsitektur serta keindahan lingkungan alam sangat potensial untuk dikembangkan sebagai daya tarik wisata. Di era modern, dalam degradasi lingkungan, sangat penting untuk meningkatkan kesejahteraan masyarakat lokal dan melestarikan lingkungan alam dalam rangka pembangunan berkelanjutan di Tabanan-Bali.
\end{abstract}

doi: https://doi.org/10.24843/blje.2020.v20.i01.p05

(C) 2019 by the authors; Content from this work may be used under the terms of the Creative Commons Attribution 3.0 licence. Any further distribution of this work must maintain attribution to the author(s) and the title of the work, journal citation and DOI. Published under licence by Udayana University, Indonesia. 
IN Wardi, dkk.; Natural Conservation Base on Management of Sacred Cultural.....

Kata Kunci: lanskap budaya sakral; catur angga batukaru; pengelolaan; konservasi

\section{Introduction}

The Batukaru Temple heritage is one of Kahyangan Jagat (state temple) in the context of cosmological structure of Nawa Sangha in Bali Island (nine magical points of Bali coordinate). The Batukaru temple is situated in the middle of the protected forest of Mount Batukaru with area \pm 11899.32 ha (Provincial Government of Bali, 2009). Batukaru temple is located in the southern foothills of Mount Batukaru at an altitude of 833 meters above sea level, i.e. including the upstream regions ( $\mathrm{kaja}$ ) of Wongaya Gede Village, District of Penebel, Tabanan Regency, Bali.

The Kahyangan Jagat Batukaru has a close relationship with four other temples, the Muncaksari, Tambawaras, Petali, and Besi Kalung Temple which are also located in the upstream region which include the District of Penebel Tabanan Regency. The structure of Batukaru Temple relationship with four other temples called Jajar Kemiri Batukaru Temple (Candlenut Row of Batukaru Temple) or Catur Angga Batukaru Temple. Catur Angga Batukaru Temple have an important role for local communities in relation to preserving the environment (forest) and its relation with the activity of cultivation of agricultural crops, especially paddy fields by the Subak institution (farmers).

According to public view in Bali (Indonesia), Tabanan known as the rice granary of Bali. The soil is very fertile which formed from layers of volcanic ash and tuff, in particular on the activities of Ancient Buyan-Bratan Volcano and Mount Batur at approximately 22,000-1,500 BC (Hadiwidjojyo, Purbo, M.M., 1978). Tropical climate with high rainfall $(3,038 \mathrm{~mm} /$ year) makes the presence of water in the Tabanan regency is relatively abundant with two lakes (Tamblingan and Bratan Lake) as the main source of water for irrigated agriculture (rice fields). In addition to the four main temples (Catur Angga), the Batukaru Temple heritage also have a cosmic magical relationship with lake temple called Ulun Danu Tamblingan (located near the upstream, i.e. the direction to the northeast of Batukaru), and the Temple of the Sea, the Pakendungan Temple / Tanah Lot Temple which situated in the southern part, exactly at Village of Beraban - District of Kediri -Tabanan Regency.

Since June 29 $9^{\text {th }}$, 2012, in Saint Peterburg-the Russian Federation, Cultural Landscape Catur Angga Batukaru Temple designated by UNESCO as part of world cultural heritage in the unity of The Cultural Landscape of Bali Province: the Subak system as a manifestation of the Tri Hita Karana Philosophy (Dinas Kebudayaan Provinsi Bali, 2013: 7). World heritage status has a positive impact on tourist visiting in the region whose numbers are likely to increase, particularly in the area of the Subak Rice-Terrace of Jatiluwih Village and Cultural Heritage of Batukaru Temple. It is very important to improve the life quality and welfare of local communities. On the other hand, the management of Cultural Landscape Catur Angga Batukaru Temple is still not optimal (there are still many obstacles), mainly related to the attention of the central government (Jakarta-Indonesia) and coordination among stakeholders (public/communities and government) at the local level. This paper is aimed to discuss the characteristic and environmental wisdom of the sacred Cultural Landscape of Catur Angga Batukaru Temple in the conservation of natural resources in the regency of Tabanan - Bali.

\section{Research Method}

To reveal the research problem, a data collection and analysis technique was carried out. Data collection was carried out with literature / document studies, observation / survey, and interview (in-depth interview). The collected data were analyzed descriptive-qualitatively using Structural-Functional and Deep Ecology theoretical approaches. Through data analysis and interpretation, it is expected to reveal the values of cultural and environmental wisdom so that they can be implemented in the management of the World Cultural Landscape of Catur Angga Batukaru Temple in Tabanan-Bali for sustainable development. 


\section{Result and Discussion}

\subsection{The Characteristic of the Cultural Landscape of Catur Angga Batukaru Temple}

In the context of cosmological structure of Sad-Kahyangan (Kahyangan Jagat) Bali Island, according to source of Babad Pasek (manuscript), cultural heritage Batukaru Temple (Batukau) as a representation of cosmic point which located at the coordinate of the Northwest. In the Babad Pasek noted, the God who enthrones Batukaru Temple namely Sang Hyang Tumuwuh (The God of Trees) (Budiastra, and Wardha, 1989). Sang Hyang Tumuwuh is another name to refer to the God or Bhatara Pucak Kedaton who enthrones at the top of Mount Batukaru (1250 m above sea level). According to Jero Mangku Gede Batukaru (temple priest), the mention of the name of Sang Hyang Tumuwuh for local people deemed taboo (very sacred/pingit). Meanwhile in cosmological of Nawa Sangha (Pangider Bhuwana) of Hinduism conception in Bali, the god who enthrones on coordinate of Northwest point, namely Dewa Sangkara. In the context of color representation, Lord Ruler of cosmic point of Northwestern part using willis color (green). This name is very suitable as the Sang Hyang Tumuwuh (the God of Threes/Mount) because it is associated with vegetation (forest). The name Sang Hyang Tumuwuh (The God of Threes/Mount) clearly indicate the name of the native Balinese who is very old (pre-Hindu). It can be interpreted that the appearance of the name Sang Hyang Tumuwuh is original name (local God) which is a symptom that influence of Hinduism in Bali on that time is not strong yet. When the influence of Hinduism culture and religious belief system get strong, then the names of Hindu's Gods began to be applied in the local cosmological system, including Sangkara God as another name for the God of Mount Batukaru (Sang Hyang Tumuwuh). Aside from the Babad Pasek source which mentioned above, the other traditional historical sources (Chronicle), is also stated that Kahyangan Jagat Batukaru serves as a compass direction Lokapala in the West space with the God figure that Mahadeva with color representation of jenar (yellow). Therefore, in the context of cosmological Jagat Bali (Pangider Bhuwana Bali) the possibility of Kahyangan Jagat Batukaru has a dual function, namely on the one hand as a god of the cosmos point of the West space (West world), and on the other side as well as the God of the cosmos of the Northwest point. The basic argument is analogous to the Kahyangan Jagat Besakih Temple (Centre of Kahyangan Jagat Bali/Mother Temple), that doubles in Pangider Bhuwana Bali i.e. as the ruler of the Northeast and as a representation of the God Çiwa who enthrones on the cosmic point in the middle.

Cultural landscape of Catur Angga Batukaru Temple now covers 9 official villages and 15 subak organizations with area $\pm 2,409$ ha of rice field. Those villages, namely: Village of Wongaya Gede, Tengkudak, Jatiluwih, Mangesta, Penatahan, Sangketan, Tegallinggah, Rejasa, and Village of Pesagi. Meanwhile Subak group included herein, namely: Subak Bedugul, Tengkudak, Wongaya Betan, Jatiluwih, Soka, Kedampal, Keloncing, Penatahan, Pesagi, Piak, Piling, Puakan, Sangketan, Tegallinggah, and Subak Rejasa.

In the context of the magical cosmology of Bali island, the position and status of Pura Batukaru classified as Kahyangan Jagat (state temple), while the fourth cultural heritages or Catur Angga (Muncaksari, Tambawaras, Pucak Petali and Besi Kalung Temple) classified as Dang Kahyangan Temple. Kahyangan Jagat means that Batukaru Temple as one of the large temple (state temple) in the system of cosmology Nawa-Sangha of Bali Island (9 magical points of Bali coordinates) as a holy place (temple) to worship the Supreme God (Sang Hyang Widhi) with all its manifestations that worshiped by all Hindu's communities in Indonesia with regardless of their social status (four castes/catur kasta: Brahmins, Ksatriyas, Wesya, Sudra). Meanwhile, the status of Dang Kahyangan means that the temple as a place of worship of God (Sang Hyang Widhi) with all its manifestations that worshiped by the public communities (Bali) and has ever been visited, used, and/or constructed in the practice of religious life by the high priest/saint (Pedanda Sakti Wawu Rawuh/Danghyang Dwijendra, Mpu Kuturan, Mpu Bharadah, Danghyang Astapaka, and other high priest). Those Supreme Priests generally derived from Java (HinduJavanese).

In the context of magical cosmic, on the fourth temples (Muncaksari, Tambawaras, Pucak Petali and Besi Kalung) are regarded as holy place of the Bala Putra as Batukaru's God family (genealogy 
relationship). Implicitly this means, that the four Gods in the temples are regarded as a representation of the power of Batukaru God. According of local perspective, the cosmic structure of Catur Angga Batukaru Temple perceived as a country or cosmic empire. In carrying out its duties and functions, Bhatara Pucak Kedaton (Sang Hyang Tumuwuh) which enthrones at the top of Mount Batukaru regarded as a king. Meanwhile, four other gods of Catur Angga (Bhatara Jajar Kemiri of Batukaru Temple) are helping to operate the government (King) to maintain the stability and the cosmic order, the securitysafety (kerahayuan), justice, prosperity and welfare of the human world and his environment.

According to the information (informants: Jero Mangku Gede Batukaru, the Mangku Catur Angga, Mangku Pura Pakerisan, Chairman of the Committee for Pangempon Pura Besi Kalung October 12-15 2015), detail of the duties and functions of the Gods who sited in the temples of Jajar Kemiri Batukaru (Catur Angga), namely:

1) Mucaksari Temple as center of Sarin Bhumi (Sari Bhuwana) or central welfare (economic aspects of farming) of local communities or also called as Bedugul Gumi/Jagat;

2) Tambawaras Temple, tamba means medicines, and duties which linked to preserve and maintain public health and the environment, particularly with farm life (Subak) in the context of the control and eradication of pests and plant diseases (especially of rice), and health in rural community life;

3) Luhur Petali Temple, analogous to a strap to maintain and preserve the unity and integrity of people in bhumi/earth (the unification of the universe), and the source of justice (in analogy with the judge) in providing protection and distribute welfare to the public at large; and

4) Besi Kalung Temple, in charge of keeping and maintaining the security sector (military), which capture and handcuff (for those who have committed crimes) offenders. In the context of farm life (Subak), Bhatara sited at Besi Kalung Temple also often requested a grace for the fertility of rice plants and other agricultural crops, for the prosperity and welfare of Subak communities and surrounding of rural communities.

According to local belief, the scope of the security tasks carried by Bhatara Besi Kalung Temple, i.e. not only in the regency of Tabanan or Bali, but within the scope of the Unitary Republic of Indonesia. One shrine (palinggih) at inner yard as a holiest yard (jeroan), which is very sacred, save a phallus artifact (Lingga).The Lingga which is located on a main shrine (Palinggih Agung) of Besi Kalung Temple is functioned as a medium for Çiwa worship. Palinggih shaped in stone throne (bebaturan) with three terraces and has three room partitions (rong tiga) as a seat for worshiping Çiwa God as a representation of three embodiments of Çiwa, namely Çiwa-Sada Çiwa-Parama Çiwa. According to the stakeholders of local and public confidence it is stated that sometimes on its place (yoni), magically Lingga moves in a certain direction, and the movement will bring certain signs related to issues of national security and public prosperity or natural disaster. Based on the experience that has ever happened, the local people believe that if stone phallus statue moves toward Southwest and Northwest, generally interpreted will bring danger signs of natural disasters or disasters caused by man himself (wars and riots) or natural disaster. According to information from stakeholders and community's leaders, since the shrine (temple) has strategic function in the field of security, it is often a numbers of officials of state government (governor, regents) and a member of the council (legislative) coming to worship the God of Çiwa which symbolized in Lingga Statue of stone terrace shrine of Besi Kalung Temple. The purposes are begging the government and Jagat Bali (Bali Island) and generally Indonesia in conditions of safety and well-being (rahayu) (informants: Jero Mangku Pura Gede Besi Kalung and I Ketut Martana / Chairman of Temple Organization, October $\left.14^{\text {th }}, 2015\right)$.

Based on the analysis of the characteristic of cosmology structure of Catur Angga Batukaru Temple (Batukaru, Muncaksari, Tambawaras, Luhur Pucak Petali, and Besi Kalung Temple) showed a symptom that the structure of the cultural landscape is based on the pattern of the relationship of four and one in the middle. The formation pattern of relationships in multiples of four is quite often found in a variety of traditional cultural expressions in Bali. For example in the ritual of mecaru/sacrificial rite (bhuta yadnya: kangin or eastward/white; kelod or southward/red; westernward/yellow; kaje or northward/black, and in the middle/mixing of those four colors/brumbun) and dewa yadnya (banten catur/catur offering), and the 
layout pattern of the traditional village with catus pata $($ catus $=$ catuh $=$ catur $=$ four $)$ or intersection as a center grand cosmic village or kingdom.

Similar views were also raised by J.L Swellengrebel and R Goris in a book entitled: Studies in Bali Life, Thoughts, and Ritual (1960). According to JL Swellengrebel, the cosmic pattern in Balinese culture, such as the concept kaje-kelod (mountain-sea) and kangin-kauh (east-west), and combinations kajekangin (north-east), and kelod-kauh (south-west) holds important role in the cosmic system of bipartite division (division dichotomies or binary oppositions) and tripartite (three division or trichotomy). In the context of sacred values, kaje (mountain) can be categorized by kangin (east), as well kauh (west) can be categorized by kelod (sea). In addition to the rules of cosmic (cosmic order) in Bali is also known for the distribution pattern of four (fourfold pattern). In the center is a synthesis and represents the union of a higher or a multiple system is also counted four to five singles (four surround a single in the middle). The division of four or five divisions are always in the horizontal size (horizontal plane). Based on the cultural phenomenon in Bali and the illustration above, then R. Goris (in Swellengrebel, J.L., 1960) stated his opinion:

"In my opinion the color division, possibly even linked with a corresponding distribution over the directions, is older than Hinduism. The four-five systems (four around the center) is also preHindu. That later Hinduism, with its pantheon, its lokapala (guardian of directions), and its colors, could easily link up to it no one will deny. It was close kinship in religious thinking that made various peoples in Indonesia such good soil, such a well-prepared field for several forms or earlier Hinduism",

Based on the above statement, explicitly R. Goris viewed that the concept of fourfold pattern (division of four) or division five, four around which surrounds one (single) in the middle, an original concept or pattern autochthonic that had existed before the entry of Hinduism culture in Bali. That is the concept of division four in the cosmic pattern in Bali is a concept that has been known in the prehistoric era Indonesia as a local cultural identity (Bali). In addition, the strong orientation impression cosmology of kaje (mountain) - kelod (sea/ocean) also showed symptoms of a prehistoric civilization, especially as the cultural identity of Austronesian's speakers. The similarity in the mindset (Bali/Indonesia-India) it facilitates the entry of the cultural influence of Hindu (India) to Bali (Indonesia). Thus, then a cultural acculturation happened which enriching the local culture, such as the division of the four sacred zones, known in the local culture (pre-Hindu) then combined with the concept of Lokapala (guardian deity of wind direction) with each colors in Hinduism.

Thus, it can be interpreted, that the characteristic of cosmological structure of Cultural Landscape Catur Angga Batukaru Temple tend to be guided by the basic conception of Catur Bhuwana (four division of world) or Padma Bhuwana (world likes a lotus blossom). The analogy of structure of Catur Angga Batukaru Temple with Padma Bhuwana can be assumed as a mandala in the form of a lotus flower, the four of flower's petals (caturdala) on a side (east-south-west-north) surrounding (protect) the essence of the flower in the middle. Even with the mention of the one of the Catur Angga Luhur Batukaru Temple called Pucak Petali (Bali's language: petali means cosmic-magical's string) can be interpreted, that Jajar Kemiri (Pecan-Row) of Catur Angga Batukaru analogous to the conception of Foating Padma Bhuwana (Padma Bhuwana Ngelayang). The conception of Padma Bhuwana Nglayang is a mandala which presupposes Catur Angga Batukaru Temple as a lotus flower floating while rotating to the circumambulation (clockwise) and associated (dependent) with the upper world (heaven world/world of deity). Thus, it can be said, that the magical cosmic of Catur Angga Batukaru Temple serves as the connecting strap (axis mundi) between the lower world/bhumi (the human world) with the upper world/heaven (world of Gods) (Patali-Nagantung). The conception of Padma Bhuwana Nglayang can be interpreted that the candlenut-row heritages (Jajar Kemiri) of Catur Angga Batukaru Temple as a mandala and symbolic center of sanctity of the region and the central screening of dharma (truth, virtue, safety, beauty, fertility, prosperity, welfare, and environmental sustainability) for life of the surrounding communities and people of Bali in general, and for the life of other creatures (sarwa prani) on earth (bhumi). 


\subsection{The Characteristic of the Cultural Landscape of Catur Angga Batukaru Temple}

Conservation closely related to resource management, especially in this case the cultural landscape of Catur Angga Batukaru Temple. The cultural landscape is entanglement between culture and nature (the interface of culture and nature), the legacy of tangible and intangible, diversity of biology and cultures their (cultural landscapes) represent a closely woven net or interrelated relationships, the essence of cultural identity and its inhabitants. They (cultural landscapes) as a symbol associated with the growing knowledge of fundamental relationships between local communities with their heritages, humanity and the natural environment. In an intimate sense, the aspects that corelated to cultural landscapes are the story of the people, and something in which the memory is made: that is a cultural richness, which promotes a sense of the local characteristic of a local distinctiveness (Rossler, 2006).

In 1992, UNESCO introduced three categories of Cultural Landscapes which has an outstanding universal value to be registered as a world heritage, namely:

1) landscape which is clearly defined and consciously designed and created by man;

2) organically evolved landscapes, divided into two groups, namely:

a) microorganisms or fossil landscape in which the evolutionary process has reached the final stages, but the descriptions are typically can still be observed;

b) continuing landscape which maintain an active social role in contemporary society in a way or a traditional way of life and in which the evolutionary process is still in progress and to show evidence of significant material from its evolution over time.

3) Associative Cultural Landscapes: namely inclusive cultural landscape that can be justified through the virtue of the religious powerful, aesthetic values, or associations of culture from the elements of nature (ecofacts) that exceeds rather than evidence of physical culture.

The category of associative cultural landscapes has contributed substantially to the recognition of intangible values and to the heritage of local communities and indigenous people. These landscapes are places with associative cultural values, some considered as sacred sites, which may be physical entities or mental images that are embedded with people's spirituality, cultural tradition and practice (Nora Mitchell, Mechtild Rössler, Pierre-Marie Tricaud). Pivotal to this is the realization that it is the places, traditions, and activities of ordinary people that create a rich cultural tapestry of life, particularly through our recognition of the values people attach to their everyday places and concomitant sense of place and identity. Identity is critical to a sense of place - genus loci - for people. Relph (1979) aptly summarizes this in his proposal that identity of place is comprised of three interrelated components, each irreducible to the other : physical features or appearance, observable activities and functions, and meaning or symbols (Taylor, Ken .2006).

Based on the types and categories of those cultural landscapes above, the cultural landscape of Catur Angga Batukaru Temple (Batukaru, Muncaksari, Tambawaras, Pucak Petali, Besi Kalung Temple), which located in the District of Penebel, Tabanan regency, can be categorized into Associative Cultural Landscape which is sacred.

Related to the concept of sacred cultural landscape, Hubert Cancik (1985/1986) stated that sacred landscape is a constellation of natural phenomena that formed as a meaningful system using artificial signs and signs of religious, by telling the names or stories that are etiological suitable for certain places and rituals that actualize the space. Further is stated, sacred landscape may also be conceived as a text prepared (formed) by natural artificial and religious icons in accordance with the rules that direct sight, perception, and movement. Sacred landscape nourishes the layers and traces the development of cultural and religious development for a very long time.

The sacredness sense in the context of resource management certainly does not mean the cultural landscape cannot be utilized, moreover which its status as a living cultural landscape such as Catur Angga Batukaru Temple. In my opinion, sacred cultural landscape like Catur Angga Batukaru always can be utilized by communities with thoughtful consideration, not intrusive the carrying capacity and ecosystems. In the context of Catur Angga Batukaru Temple, in praxis the sacred cultural landscape can be interpreted in the multiple significances. Among those things namely: (1) there is a cosmic-magical value contained 
therein, (2) a very strategic position (upstream area: catchment and infiltration of rain water and habitat of biodiversity's), (3) the ecosystem is unique (not yet revealed completely) and its potential is limited, (4) there are many interests of the local people regarding the basic needs which related to survival or fate of life and death of local residents, (5) the use of available resources should be done carefully and wisely, (6) the preservation and welfare of the people life and another creatures (sarwa prani) to keep awake and be properly maintained.

Indirectly in the context of the conservation of sacred cultural landscape, the position of Catur Angga Batukaru Temple is also strengthened by the Bali Provincial Regulation No. 16/2009 on Spatial Planning. Therein is mentioned about the sanctity of the temple radius (karang kekeran) adopted from The Bhisama Parisadha Hindu Dharma Indonesia (PHDI) 11/Kep./I/PHDI/1994 (Provincial Government of Bali, 2009). Related to the sanctity of the temple radius (karang kekeran) in which it is declared:

1) Sad Kahyangan Temple applied radius apaneleng agung (grand view-size at least $5 \mathrm{~km}$ from the temple);

2) Dang Kahyangan Temple applied radius apeneleng alit (short view-size at minimum $2 \mathrm{~km}$ from the temple); and

3) Kahyangan Tiga Temple (Three Main Temples for The God of Tri Murti worship in the village) and other temples applied radius apanimpug (size as far as stone throwing of adult people) or apenyengker (temple wall limit).

It is explained that in the area of the radius of the sanctity of the temple (the karang kekeran) there should only be a building associated with the life of the Hindu religion, such as dharmasala, religious hostel, and other facilities for the convenience of Hindus which perform religious activities (tirthayatra, dharmawacana, dharmagitha, dharmasadana, and other activities). This means that within a radius of the sanctity of the temple is only allowed for the construction of religious facilities and open space that can be either green open space and open space for agriculture.

Then with regard to conservation can be defined as the process of managing change to a place that is considered as significant place in the layout by means of which it will be the best way to preserve heritage values. Meanwhile from the opportunities that are already known, seeks to uncover or empower those values for the present generation and the generations in the future. In an operational definition above indirectly accept any changes in cultural values in the course of time, and actually change the values that may occur by the conservation process itself. In addition, the conservation objectives are not only concerned with the future generations, but also the current generation (Taylor, Ken, 2006).

The purpose of management of cultural landscapes inscribed on the World Heritage List is to protect the outstanding universal value for present and future generations. It is the role of management to guide change in the cultural landscape while retaining important values. Effective management involves a cycle of long-term and day-to-day actions to protect, conserve and present the World Heritage property. A thorough and shared understanding of the property by all stakeholders a cycle of planning, implementation, monitoring, evaluation and feedback; the full involvement of partners and stakeholders; the allocation of necessary resources capacity-building and an accountable, transparent description of how the management system functions. There are several inter-related components in the recommended management approach. Three of them - guiding principles, management processes and sustaining management.

Cultural aspects of the landscape should be conserved or given protection, which involves authenticity and the integrity aspects of the cultural landscape. According to the operational guidance for the management of the Cultural Landscape of UNESCO which adopted from the 1994 Nara Conference recognized that the concept of the "test of authenticity" should not be limited to the four aspects described in the Operational Guidelines of the time: material, design, workmanship, setting and in the case of cultural landscapes their distinctive character and components. Accordingly, in the Nara Document on Authenticity, knowledge and understanding of original and subsequent characteristics of cultural heritage, their meanings, and sources of information are a prerequisite for assessing all aspects of authenticity, including form and design, materials and substance, use and function, traditions and techniques, location 
and setting, language and other forms of intangible heritage, spirit and feeling (Nora Mitchell, Mechtild Rössler, Pierre-Marie Tricaud).

Since 2005, all properties nominated must satisfy the conditions of integrity. This was specifically requested by many global, regional and thematic expert meetings on cultural landscapes. The meaning of the word integrity is wholeness, completeness, unimpaired or uncorrupted condition, continuation of traditional uses and social fabric (Nora Mitchell, Mechtild Rössler, Pierre-Marie Tricaud).

In the conservation of cultural heritage and historic environment, the value of significance (importance) should be the starting point. The principles of conservation of the heritage of British defines the value of significance (importance), namely "the total value of the cultural heritage and natural heritage of a particular place, often designed (set out) in a statement of significance (significance). If further elaborated, a value is an aspect of value or importance, attached by the people against the quality areas. Those values are grouped into four major segments, namely:

a) evident, which is derived from places potential to show evidence about the activities of human life in the past;

b) historic (historic), which is derived from human ways in the past, events and other aspects of life can be connected via a spot on today;

c) aesthetics, which is derived from the ways in which the human past through the draw sensory and intellectual stimulation from somewhere;

d) communal, which is derived from the meaning of a place for people associated with buildings / historic neighborhood it, or to whom it was depicted in their collective experience or memory of (their collective experience or memory).

A common theme underpinning the concept of the ideology of landscape itself as the setting for everything we do is that of the landscape as the repository of intangible values and human meanings that nurture our very existence. This is why landscape and memory are inseparable because landscape is the nerve center of our personal and collective memories (Taylor, Ken.2006).

In the context of Catur Angga Batukaru Temple, the conservation which is intended namely the conservation of the cultural approach, especially magical religious ritual, held at the Catur Angga Batukaru Temple associated with maintenance (conservation) of natural resources, particularly water resources (lakes, rivers, and springs), forest, land and rice plants. Conservation in the management of sacred cultural landscape Catur Angga Batukaru Temple contains three main components of the environment i.e. human - nature - Gods which are summarized in the concept of Tri Hita Karana.

Associative Cultural Landscape Concept in the nuance of Tri Hita Karana implies the condition of a balanced relationship and harmony between human beings with one another, with the natural resources and the environment around them, and with God who is manifested in various dimensions of culture and belief systems. Various dimensions of cultures and belief systems, among them, namely the belief system (belief in the God of the mountain, the water God, ancestral spirits, and other Gods), artifacts, monuments/architecture, activities and rituals of agriculture (Subak), history, myths and taboos, sacred sites, cultural arts, such as performing arts and literature, the art of traditional songs, music art (gamelan/gong), and aspects of ecofacts i.e. trees, rocks, water and other ecofact form that is deemed sacred. Cultural Landscape concept in nuance of Tri Hita Karana implicitly contains awareness and enthusiasm for life (awareness and spirit of life) are diverse and holistic integrated (Bhineka Tunggal Ika). Cultural Landscape in nuance of Tri Hita Karana is also based on the principle in view of coexistence and tolerance of various ways of life and objects in the zone of earth's biosphere, either with human beings (human society), plants (flora), fauna and the existence of abiotic natural resources (physical and chemical) as a creation of God (Sang Hyang Widhi), so that they can live together (coexisting) in a harmonious and sustainable condition.

The values of the sanctity of Cultural Landscape of Catur Angga Batukaru Temple are kept, maintained and powered continuously by the Subak and village communities through the maintenance of sacred buildings (temple), ritual of farming and other rituals at their respective of cultural heritage (temple) and the natural environment (mountains, forests, lakes, river, and land). Subak rituals and other 
rituals conducted by temple organization (pangempon pura) regularly based on astronomical calculations (Calendar of Bali). Among the ritual of magical-religious which related to natural resources and the environment, namely: 1) Mulang Pakelem in ritual of Mapag Toya (sacrifice ritual for water welcoming); 2) ritual of Nawur Sarin Tahun (annually crops payment ritual), (3) ritual piodalan (birth day ritual) which is held in every six months on each temple, and other rituals. Subak communities in Tabanan (Catur Angga Batukaru Temple), commonly practice three kinds of rituals Mendak Toya made every year (every full moon in October/Purnama Sasih Kapat). The annual ritual successively performed, namely: 1) the ritual in the full moon of Sasih Kapat I (October), is held at the summit of Mount Batukaru, 2) full moon of Sasih Kapat II in upstream of Mawa River, and 3) the full moon of Sasih Kapat III on the Lake Tamblingan. After the ritual Pakelem (Mapag Toya), then continued with the ritual at the level of lower Subak institution to deliver the process of cultivation in paddy fields.

According to Mangku Gede Batukaru Temmple (Temple Priest), ritual significance of Pakelem (Mendak Toya) is very closely related to the conservation of water resources, especially natural water that comes from rainwater and then deposited in a lake and rivers which then flow through. So, the lake (Tamblingan Lake) regarded as a natural pond, as rainwater catchment. The ritual of Pakelem (Mapag Toya) is symbolically significant: that is like laying a foundation in the development process, so that the building would has a strong base. When its base essentially already strong, then when there is a blessing of rain fell from the sky, the water accommodated in the natural pond (lake). If the water reservoir (lake) is already strong, good with full of waters, then the water will flow downstream; The lake's water will flow in regularly, as a source of fertility, prosperity, and welfare for society, particularly for farmers (Subak) in cultivation of rice plants. Implicitly ritual of Mapag Toya bears etnosains containing the environmental wisdom which associated with aquatic ecosystems (rain) with mountains, forests, lakes, rivers, and agricultural ecosystems in the fields. Likewise, among other meanings and expectations of the community of farmers and villagers associated with the delivery of the pakelem ritual.

Another important ritual is the ceremony of nawur sarin tahun (annually crops payment ritual) or offering yields of Subak. Offerings of crops (rice) and sesari (money) made by Subak institution to sacred places (temples) as God's palace while begging holy water (tirtha/pakuluh) for safety, fertility and prosperity for crops and communities. Then after a successful harvest (everyone cycles of rice cultivation) they offered sarin tahun, for example nawur sarin tahun at subak temple (Bedugul Temple), at Kahyangan Jagat Batukaru Temple, Catur Angga Temple (Muncaksari, Tambawaras, Pucak Petali and Besi Kalung Temple).

Sarin Tahun offerings in this sense has a double meaning. On the one hand, the offerings of sarin tahun and worshiping is meant as an expression of gratitude and thanks for the blessings that have been received from the Gods who enthrone in the temples. The second meaning, namely the ritual of sarin tahun offering, intended that the Subak community also seek blessings of salvation, fertility, prosperity for next rice cultivation in the form of ritual worship and supplication holy water (tirtha) will be taken and sprinkled on the wetland (paddy) of farmers in the neighborhood of subak communities respectively. To the ritual of ngaturang (nawur) sarin tahun (annually crops payment ritual) and please taking holy water (tirhta) of Bhatara/Bhatari for safety, fertility and prosperity of the farmers, according to local tradition is called the Ngempak-Ngulanting (touching while clinging to a tree).

Meanwhile, ritual piodalan also called partir than is a kind of ritual associated with the holy day of the establishment and inauguration of the sacred building (celebrated every 6 months or 210 days, according to calculations of Balinese calendar) which is regarded as the birthday of God / Bhatara who enthrones in the temple. Ritual of piodalan on Catur Angga Batukaru Temple generally lasts (nyejer) for 3 days. Indirectly, cultural value system that is practiced by society in the form of ritual, taboo, and the myths associated with the surrounding area, creating, and maintaining the values of sanctity (sacredness) for landscapes of Catur Angga Batukaru Temple. Sacredness, existence of taboo and myths associated with the existence of natural resources make people do not dare to violate (ngusak-asik) and damaging the natural environment (forests, lakes, springs, rivers) so that it can contribute to the value of preserving the environment and natural resources.

Sanctity's vibration of Sang Hyang Tumuwuh (Bhatara Pucak Kedaton), the Gods and ancestral spirits who enthrone in the Batukaru Temple and Catur Angga Temple (Muncaksari, Tambawars, Pucak 
Petali and Besi Kalung) creating natural environment of Batukaru considered very sacred (seclusion), such as talking should not boast (cuah-cauh), keeping away from attitude and behavior of damaging and disturbing the surrounding. Thus, the consequence is that the environmental conditions of forests and biodiversity in the region of Catur Angga Batukaru Temple growing well and developing naturally and environmentally be sustainable. According to the Head of the Forest Protection Officer of Forestry Department of Tabanan Regency (informant: I Gst W. Sukarsa, September $17^{\text {th }}, 2015$ ), the value of the sanctity of the area or the environment has to do with the environment. The farther the radius of the vortex sanctity (sanctity) of Pucak Kedaton Temple/Batukaru Temple (Catur Angga Batukaru Temple), then there is the emerging trend of citizen courage to commit abuses and disruption to the forest conservation and the biodiversity contained therein. According to him, violations such as illegal logging and encroachment into forest conservation industry (cultivation of cocoa and other economically valuable crops) tends to occur in the outside of the sacred area of Catur Angga Batukaru Temple.

In addition, the rituals associated with rice cultivation in paddy fields, indirectly implies that the farming communities (Subak) in the highlands (mountainous or region of Batukaru) has been conserving local rice varieties, in which the local rice varieties elsewhere in Bali is already almost extinct.

\section{Conclusions}

The cultural landscape of Catur Angga Batukaru Temple (Batukaru, Muncaksari, Tambawaras, Pucak Petali, Besi Kalung Temple) can be categorized into an Associative Cultural Landscape which is sacred. The characteristic structure of Cultural Landscape of Catur Angga Batukaru Temple based on the concept of Catur Bhuwana or Padma Bhuwana Nglayang. The conception of Padma Bhuwana Ngelayang can be interpreted that Catur Angga Batukaru Temple as a mandala, and the symbol of center sanctity of the region and the central screening of dharma (truth, virtue, safety, beauty, fertility, prosperity, welfare, and environmental sustainability) for life in the surrounding communities and the people of Bali in general, and for the life of other creatures (sarwa prani) on earth (bhumi). The sacredness of the area (Cultural Landscape of Catur Angga Batukaru Temple) maintained and guarded with the maintenance of sacred buildings (temple), ritual (Mapag Toya, Sarin Tahun, piodalan/temple festival, and other rituals), taboo, myth, to glorify and worship the God of nature (God of the mountain, God of the sky/rain, the God of lake, the God of sun, the God of rice), ancestral spirits, and other holy beings. If the values of environmental wisdom as environmental ethics contained in Sacred Landscape Catur Angga Batukaru Temple (sacred padma bhuwana nglayang) combined with The Regional Regulation of Bali No.16/2009 about region Spatial Planning, then the position of the conservation of the natural environment in the region of Batukaru should be strong enough to support the sustainable development. But all these things will certainly continue to be tested in practice of governmental management (commitment) and social interaction of everyday life of the communities, namely the extent to which the values of environmental ethics of Sacred Cultural Landscape Catur Angga Batukaru Temple and positive law (government regulations) would be implemented.

\section{References}

Budiastra, Putu dan Wardha, Wayan.1989. Babad Pasek Kayu Selem. Denpasar.

Cancik, Hubert. (1985/1986). Rome As Sacred Landscape: Varro and The End of Republican Religion in Rome" dalam Visible Religion For Religious Iconography; Volume IV-V. Leiden, E.J. Brill; (p.250265).

Dirjen Sejarah dan Purbakala. 2010. Undang-Undang Republik Indonesia Nomor 11 Tahun 2010 tentang Cagar Budaya. Jakarta.

Goris, R. 1960. "The Temple System" in Bali Studies in Life, Thought, and Ritual. Amsterdam: The Royal Tropical Institute.

Pemerintah Provinsi Bali. 2009. Peraturan Provinsi Bali Nomor 16 Tahun 2029 tentang Rencana Tata Ruang Wilayah Provinsi Bali Tahun 2009-2029. Denpasar. 
Purbo-Hadiwidjono,M.M. (1978). Dasar-Dasar Geologi Untuk Pengembangan P.Bali. Bandung. (pp 8389).

Swellengrebel, J.L. (1960). Patterns of The Cosmic Order in Bali Studies in Life, Thoughts, and Ritual. Hague and Bandung: The Royal Tropical Institute-Amsterdam.W.van Hoeve Ltd.

Taylor, Ken. 2006. Landscape and Memory: cultural landscapes, intangible values and some thoughts on Asia. Australia: Research School of Humanities The Australian National University Canberra ACT 0200 . 